\title{
STATISTICAL CONTROL OF THE PROCESS APPLIED TO THE MONITORING OF THE WATER QUALITY INDEX
}

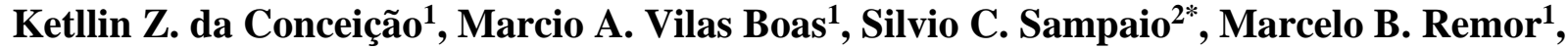 \\ Danilo I. Bonaparte ${ }^{3}$
}

${ }^{2 *}$ Corresponding author. Universidade Estadual do Oeste do Paraná/ Cascavel - PR, Brasil. silvo.sampaio@unioeste.br

\section{KEYWORDS}

water quality index, control charts, capacity of the process.

\begin{abstract}
Analyzing the physical-chemical and biological characteristics allows the evaluation of the water quality of a water body. Thus, the objective of this study was to determine the water quality index of the Passaúna and Piraquara rivers, as well as to apply statistical quality control methodologies to evaluate the data resulting from the monitoring of water quality. Therefore, a database with physico-chemical and microbiological parameters of the Passaúna and Piraquara rivers, a watershed of the Iguaçu River, belonging to the cities of Araucária and Piraquara, respectively Paraná, Brazil, was used to carry out the research. The water quality index was determined with the time series and, subsequently, these data were submitted to the statistical control of the process, with the control charts of individual Shewhart, EWMA and CUSUM, in addition to the development of the process capacity index. The WQI detected that the rivers remained in average quality until the year 2000, however, from that year it was possible to see a decreasing trend in the water quality of the evaluated rivers. The control charts of Shewhart, EWMA, CUSUM and the process capability index were able to identify the decreasing trend in water quality, demonstrating that they are fast and efficient techniques for the evaluation of water quality control.
\end{abstract}

\section{INTRODUCTION}

The large-scale growth of large urban centers and industrial development contribute to the process of degradation of water resources (Oliveira et al., 2017, Santos et al., 2018). The Water Quality Index (WQI) is a tool that presents clearly the conditions about a water body in the form of a ranking, and is essential to take specific or generalized preventive measures (Fernandes \& Scalize, 2015).

The WQI is considered a rapid and systematic tool for the evaluation and classification of water characteristics. This indicator is calculated by the weighted output of selected parameters, and from the result obtained, the quality of the water body is classified between poor and optimal, relating a range of WQI variation (0-100) (Oliveira Pinto et al., 2015). Several techniques can be used to monitor environmental factors. Carvalho et al. (2016) argue that, increasingly, statistical techniques have been contributing to the monitoring of aquatic ecosystems.
Statistical process control (SPC) is a powerful tool for problem detection, demonstrating process stability and capacity improvement by reducing variability. The SPC is able to quickly detect changes in a process, enabling to occur an investigation and corrective action, before a large number of nonconformities begin to occur. Among the main tools used in statistical process control are control charts. These graphs are monitoring techniques capable of demonstrating how the process is developing (Montgomery, 2004). For this study, three control charts, the individual Shewhart, the exponentially weighted moving average (EWMA) and the cumulative sum (CUSUM) were tested. Although these statistical process control techniques are widely used in industrial processes, Montgomery 2004 states that they can also be applied to non-industrial processes. In this sense, the applicability of these techniques has demonstrated an effectiveness in the most diverse areas of knowledge.

Reis et al. (2011) evaluated the water quality for irrigation purposes in rural properties in the municipality of Salto do Lontra - PR, using individual Shewhart charts; as well as, Follador et al. (2012a) used the CUSUM charts

${ }^{1}$ Universidade Estadual do Oeste do Paraná/ Cascavel - PR, Brasil.

${ }^{3}$ Centro Universitário Fundação Assis Gurgacz/ Cascavel - PR, Brasil.

Received in: 6-6-2018

Accepted in: 8-20-2018 
to evaluate the quality of the Mandurim River, the Marrecas River Basin, Southwest Paraná; Orsatto et al. (2015) who evaluated the performance of a sewage treatment plant through exponentially weighted moving average statistical quality control charts; and Frigo et al. (2016) who used the Shewhart control charts, exponentially weighted moving average and cumulative sum, to evaluate the quality of a conventional sprinkler irrigation system.

To define how much a process is capable of reaching the expected specifications, the process capability index is calculated. This index is measured so that the competence of a process can be verified. In this way, when it is necessary to calculate the capacity index of the process, the variation with the necessary limits is compared, being higher and/or lower (Montgomery, 2004; Orsatto et al., 2015).

In this context, the objective of this study was to quantify the water quality in the urban stretch of the Passaúna and Piraquara rivers, identifying which tool of statistical control of the process is most adequate for the monitoring of water quality.

\section{MATERIAL AND METHODS}

\section{Obtaining the Database}

The water quality database containing the total solid parameters, temperature turbidity, biochemical oxygen demand, total phosphorus, dissolved oxygen, hydrogenionic potential, total nitrogen and thermotolerant coliforms was provided by the Instituto das Águas do Paraná. The data refer to the collections made quarterly in the period from 1987 to 2008 for the Passaúna River (Campina das Pedras, Araucária Municipality, latitude $25^{\circ} 34^{\prime} 28^{\prime \prime}$ and longitude $\left.49^{\circ} 25^{\prime} 47^{\prime \prime}\right)$ and from 1991 to 2017 for the Piraquara river (treatment station Ponte Estrada Piraquara, municipality of Piraquara, latitude $25^{\circ} 23^{\prime} 42^{\prime \prime}$ and longitude $49^{\circ} 03$ '20"), metropolitan region of Curitiba - PR. According to CONAMA Resolution 357/2005, the Passaúna and Piraquara rivers are classified as Class 2 rivers. These watersheds belong to the Iguaçu River basin.

The Water Quality Index (WQI) was developed to evaluate the quality of raw water for use in public water supply (ANA, 2016). The WQI consists of nine parameters: total solids $(\mathrm{w}=0.08)$, turbidity $(\mathrm{w}=0.08)$, temperature $(\mathrm{w}=0.10)$, biochemical oxygen demand $(\mathrm{w}=$ 0.10 ), total phosphorus ( $\mathrm{w}=0.10)$, dissolved oxygen (wi $0.17)$, hydrogenionic potential $(\mathrm{w}=0.12)$, total nitrogen ( $\mathrm{w}$ $=0.10)$, and thermotolerant coliforms $(\mathrm{w}=0.15)$, with their respective weights $(\mathrm{w})$, which were fixed according to their importance for the overall conformation of water quality (ANA, 2016). The WQI calculation is done by means of the weighted output of the nine parameters, according to [eq. (1)].

$$
\mathrm{WQI}=\prod_{\mathrm{i}=1}^{\mathrm{n}} \mathrm{qi}^{\mathrm{wi}}
$$

Where,

$\mathrm{WQI}=$ Water Quality Index, which ranges from 0 to 100 ;

$\mathrm{q} i=$ quality of the $\mathrm{i}^{\text {th }}$ parameter. A number between 0 and 100 , obtained from the respective quality chart, depending on its concentration or measurement (analysis result);

wi $=$ weight corresponding to the $\mathrm{i}^{\text {th }}$ parameter, ranging from 0 to 1 .

The value of qi is obtained from the respective quality chart as a function of its concentration or measure. With WQI values calculated, the water quality level is classified into the following ranges: Excellent $(91<\mathrm{WQI} \leq$ 100); Good (71 <WQI $\leq 90)$; Medium (51 <WQI $\leq 70)$; $\operatorname{Bad}(26<\mathrm{WQI} \leq 50)$ and Very $\operatorname{Bad}(0<\mathrm{WQI} \leq 25)(\mathrm{ANA}$, 2016).

\section{Control Charts}

Control charts are hypothesis tests where the process is in a state of statistical control, that is, a plot point within the control limits is equivalent to not rejecting the statistical control hypothesis and a plot point out of bounds is equivalent to the rejection of this hypothesis (Montgomery, 2004). The control charts were generated in MINITAB 16® software.

The Shewhart Individual control chart is characterized by three lines: the Central Line (CL) defined by the mean of the data set; the Upper Control Line (UCL) and the Lower Control Line (LCL), obtained by eqs (2), (3) and (4) (Montgomery, 2004):

$$
\begin{aligned}
& \mathrm{CL}=\mu \\
& \mathrm{UCL}=\mu+3 \frac{\mathrm{AM}}{\mathrm{d}_{2}} \\
& \mathrm{LCL}=\mu-3 \frac{\mathrm{AM}}{\mathrm{d}_{2}}
\end{aligned}
$$

Where,

$$
\begin{aligned}
& \mathrm{CL}=\text { medium line; } \\
& \mu=\text { Medium observations; } \\
& \mathrm{UCL}=\text { upper control limit; } \\
& \mathrm{LCL}=\text { lower limit of control; } \\
& \mathrm{AS}=\text { amplitude of the sample, } \\
& \mathrm{d}_{2}=\text { factor for construction of variable control chart. }
\end{aligned}
$$

The exponentially weighted moving average graph (EWMA) is also characterized by three lines: CL, UCL, LCL. This graph model is commonly used in time series modeling and forecasting. The EWMA chart is ideal for using with individual observations (Montgomery, 2004). The exponentially weighted moving average graph is defined by [eq. (5)].

$$
\mathrm{Z}_{\mathrm{i}}=\lambda \mathrm{x}_{\mathrm{i}}+(1-\lambda) \mathrm{z}_{\mathrm{i}-1}
$$

Where,

$$
\begin{aligned}
& \mathrm{Z}_{\mathrm{i}}=\text { values of the } \mathrm{i}^{\text {th }} \text { observation; } \\
& \mathrm{X}_{\mathrm{i}}=\mathrm{i}^{\text {th }} \text { observed value; } \\
& \lambda=\text { constant ranging from } 0 \text { to } 1(0<\lambda \leq 1), \\
& \mathrm{Z}=\text { target value or mean value in control. }
\end{aligned}
$$


The center line and the upper and lower control limits (UCL and LCL) of the EWMA graph are given by eqs (6), (7) and (8).

$$
\begin{aligned}
& \mathrm{UCL}=\mu_{0}+\mathrm{L}_{\sigma} \sqrt{\left(\frac{\lambda}{(2-\lambda)}\right)}\left[1-(1-\lambda)^{2 \mathrm{i}}\right] \\
& \mathrm{CL}=\mu \\
& \mathrm{LCL}=\mu_{0}-\mathrm{L}_{\sigma} \sqrt{\left(\frac{\lambda}{(2-\lambda)}\right)}\left[1-(1-\lambda)^{2 \mathrm{i}}\right]
\end{aligned}
$$

Where,

$$
\mu_{0}=\text { average of observations; }
$$

$\lambda=$ constant ranging from 0 to 1 ;

$\mathrm{L}_{\sigma}=$ number of standard deviations of the control mean to be detected,

$\mathrm{I}=$ order of the sample used.

The cumulative sum control chart (CUSUM) is a good alternative when minor changes are important. This graph directly incorporates all the information in the sequence of sample values, plotting the cumulative sums of the deviations of the sample values from a target value (Montgomery, 2004). The CUSUM graph is defined according to [eq. (9)].

$$
\mathrm{C}_{\mathrm{i}}=\sum_{\mathrm{j}=1}^{\mathrm{i}}\left(\mathrm{X}_{\mathrm{j}}-\mu_{0}\right)
$$

Wherein:

$$
\begin{aligned}
& \mathrm{X}_{\mathrm{j}}=\text { mean of the } \mathrm{j}^{\text {th }} \text { size sample } \mathrm{n} \geq 1, \\
& \mathrm{C}_{\mathrm{i}}=\text { cumulative sum up to the } \mathrm{i}^{\text {th }} \text { sample. }
\end{aligned}
$$

The CUSUM is the tabulation of the accumulation of $\mu_{\mathrm{o}}$ derivations that are above the target with $\mathrm{a} \mathrm{C}^{+}$ statistic and accumulating derivations of $\mu_{0}$ that are below the target with another $\mathrm{C}^{-}$statistic. These statistics are called upper and lower CUSUM, calculated by eqs (10) and (11).

$$
\begin{aligned}
& \mathrm{C}_{\mathrm{i}}^{+}=\max \left[0 ; \mathrm{x}_{\mathrm{i}}-\left(\mu_{0}+\mathrm{K}\right)+\mathrm{C}_{\mathrm{i}-1}^{+}\right] \\
& \mathrm{C}_{\mathrm{i}}^{-}=\max \left[0 ;\left(\mu_{0}+\mathrm{K}\right)-\mathrm{x}_{\mathrm{i}}+\mathrm{C}_{\mathrm{i}-1}^{+}\right]
\end{aligned}
$$

Where,

$$
\begin{aligned}
& \mathrm{xi}=\text { observation in time; } \\
& \mathrm{Ci}=\text { cumulative sum up to the } \mathrm{i}^{\text {th }} \text { sample, can be } \\
& \text { negative or positive; } \\
& \mathrm{K}=\text { compensation value or clearance. }
\end{aligned}
$$

\section{Process Capability}

When using the process capability tool, it is necessary to verify that stability will yield satisfactory results from the level of quality being sought. The control graphs help in this verification and, if process instability is perceived, then the behavior of the process capacity will be unstable, not requiring its investigation (Giron et al., 2013). The verification of process stability is obtained by using [eq. (12)].

$$
\mathrm{C}_{\mathrm{p}}=\frac{\text { LSE-LIE }}{\text { UCL-LCL }}
$$

Where,

$$
\begin{aligned}
& \mathrm{C}_{\mathrm{p}}=\text { Process Capability } \\
& \mathrm{ULS}=\text { upper limit of specification; } \\
& \mathrm{LLS}=\text { lower limit of specification; } \\
& \mathrm{ULC}=\text { upper limit of control, } \\
& \mathrm{LLC}=\text { lower limit of control. }
\end{aligned}
$$

According to Montgomery (2004), the Cp measures the potential capacity of the process, while the variable $C_{p k}$ measures the actual capacity of the process allowing to evaluate if the process will be able to reach the desired value. The variable $C_{p k}$ is defined according to eqs (13), (14) and (15).

$$
\begin{aligned}
& \mathrm{C}_{\mathrm{pk}}=\operatorname{Min}\left\{\mathrm{C}_{\mathrm{pu}}, \mathrm{C}_{\mathrm{pI}}\right\} \\
& \mathrm{C}_{\mathrm{pu}}=\frac{\mathrm{ULS}-\mu}{3 \hat{\sigma}} \\
& \mathrm{C}_{\mathrm{pI}}=\frac{\mu-\operatorname{LLS}}{3 \hat{\sigma}}
\end{aligned}
$$

\section{RESULTS AND DISCUSSION}

\section{Analysis of descriptive statistics}

Table 1 presents the results of the descriptive statistics of the physicochemical parameters and the WQI. It is observed that, considering the average values, the thermotolerant coliform parameters and total phosphorus are outside the reference values stipulated by the resolution of CONAMA $357 / 2005$ in both cities. In this sense, the WQI calculation classifies the water quality of the rivers Passaúna and Piraquara as average quality. 
TABLE 1. Descriptive statistics of the parameters analyzed by the water quality index in the Passaúna river, in Araucária and Piraquara river, Piraquara - PR.

\begin{tabular}{|c|c|c|c|c|c|c|c|}
\hline \multicolumn{8}{|c|}{ Passaúna River } \\
\hline Parameter & Average & DP & Min. & Max. & $\mathrm{AC}$ & $\mathrm{KC}$ & CONAMA 357/2005 \\
\hline $\mathrm{DO}$ & 5.59 & 1.65 & 1.30 & 8.90 & -0.27 & -0.60 & $\geq 5 \mathrm{mg} \mathrm{L}^{-1}$ \\
\hline Cte & 58569 & 248082 & 20 & 1700000 & 5.94 & 36.05 & $\leq 1000 \mathrm{NMP} 100 \mathrm{~mL}$ \\
\hline $\mathrm{pH}$ & 7.24 & 0.31 & 6.20 & 8.10 & -0.11 & 1.40 & 6.0 a 9.0 \\
\hline BOD & 4.02 & 3.79 & 1.00 & 31.00 & 4.20 & 26.81 & $\leq 5 \mathrm{mg} \mathrm{L}^{-1}$ \\
\hline $\mathrm{N}$ & 2.01 & 1.60 & 0.47 & 8.00 & 1.95 & 3.86 & subtitle \\
\hline $\mathrm{P}$ & 0.12 & 0.12 & 0.005 & 0.78 & 2.92 & 12.13 & $\leq 0.050 \mathrm{mg} \mathrm{L}^{-1}$ \\
\hline Tur & 24.48 & 39.90 & 1.40 & 308.00 & 4.76 & 28.42 & $\leq 100 \mathrm{UNT}$ \\
\hline $\mathrm{TS}$ & 124.04 & 40.00 & 5.00 & 234.00 & 0.17 & 0.51 & $\leq 500 \mathrm{mg} \mathrm{L}^{-1}$ \\
\hline $\mathrm{T}$ & 18.50 & 3.11 & 13.00 & 26.00 & 0.31 & -0.63 & Should not be elevated \\
\hline WQI & 60.41 & 12.04 & 23.00 & 85.00 & -0.33 & -0.10 & -- \\
\hline \multicolumn{8}{|c|}{ Piraquara River } \\
\hline DO & 8.24 & 0.76 & 6.10 & 9.70 & -0.31 & -0.38 & $\geq 5 \mathrm{mg} \mathrm{L}^{-1}$ \\
\hline Cte & 35832 & 108935 & 20 & 700000 & 4.52 & 22.19 & $\leq 1000 \mathrm{NMP} 100 \mathrm{~mL}$ \\
\hline $\mathrm{pH}$ & 6.80 & 0.42 & 5.70 & 8.00 & -0.40 & 0.62 & 6.0 to 9.0 \\
\hline BOD & 2.61 & 1.96 & 1.00 & 11.00 & 2.60 & 7.86 & $\leq 5 \mathrm{mg} \mathrm{L}^{-1}$ \\
\hline $\mathrm{N}$ & 0.74 & 0.43 & 0.32 & 2.46 & 1.94 & 4.71 & legend \\
\hline $\mathrm{P}$ & 0.07 & 0.08 & 0.002 & 0.62 & 4.23 & 22.76 & $\leq 0.050 \mathrm{mg} \mathrm{L}^{-1}$ \\
\hline Tur & 17.43 & 14.72 & 0.90 & 120.00 & 4.60 & 29.70 & $\leq 100 \mathrm{UNT}$ \\
\hline TS & 77.58 & 32.58 & 25.00 & 211.00 & 1.02 & 2.32 & $\leq 500 \mathrm{mg} \mathrm{L}^{-1}$ \\
\hline $\mathrm{T}$ & 17.60 & 2.83 & 10.00 & 23.00 & -0.40 & -0.59 & Should not be elevated \\
\hline WQI & 64.86 & 9.04 & 41.00 & 79.00 & -0.53 & -0.09 & -- \\
\hline
\end{tabular}

AC: asymmetry coefficient; KC: kurtosis coefficient; DO: dissolved oxygen ( $\left.\mathrm{mg} \mathrm{L}^{-1}\right)$; Cte: thermotolerant coliforms (NMP / 100mL); $\mathrm{pH}$ : hydrogenation potential; BOD: biochemical oxygen demand $\left(\mathrm{mg} \mathrm{L}^{-1}\right)$; $\mathrm{N}$ : Nitrogen $\left(\mathrm{mg} \mathrm{L}^{-1}\right)\left(3.7 \mathrm{mg} \mathrm{L}^{-1}\right.$ of $\mathrm{N}$ for $\mathrm{pH} \leq 7.5 ; 2.0 \mathrm{mg} \mathrm{L} \mathrm{L}^{-1}$ of $\mathrm{N}$ for $7.5<\mathrm{pH} \leq 8.0 ; 1.0 \mathrm{mg} \mathrm{L}^{-1}$ of $\mathrm{N}$ for $8.0<\mathrm{pH} \leq 8.5 ; 0.5 \mathrm{mg} \mathrm{L}^{-1}$ of $\mathrm{N}$ for $\mathrm{pH}>8.5$ ); P: phosphorus (mg L-1); Tur: turbidity (UNT); TS: total solids $\left(\mathrm{mg} \mathrm{L}^{-1}\right)$; T: temperature $\left(\mathrm{C}^{\circ}\right)$; WQI: water quality index.

Table 2 presents the comparison between the WQI values found in this study with other regions of Brazil. It is observed that rivers near the urban regions have a lower WQI when compared to those of rural regions. The reduction in the WQI value in urban areas is mainly due to the increase in the variable thermotolerant coliforms.
According to Carvalho et al. (2016) the high concentration of thermotolerant coliforms in rivers comes from fecal pollution. The WQI is a quality index in which the parameters analyzed are primarily negatively affected by domestic sewage inflow. Thus, highly urbanized areas generally have lower WQI.

TABLE 2. Water Quality Index in fluvial environments in Brazil.

\begin{tabular}{|c|c|c|c|c|c|c|}
\hline \multirow{2}{*}{ Place } & \multicolumn{2}{|c|}{ Coordinates } & \multicolumn{3}{|c|}{ WQI } & \multirow{2}{*}{ Reference } \\
\hline & Latitude (S) & Longitude (W) & Min. & Ave. & Max. & \\
\hline Araucária River - PR & $25^{\circ} 34^{\prime} 28^{\prime \prime}$ & $49^{\circ} 25^{\prime} 47^{\prime \prime}$ & 23.0 & 60.4 & 85.0 & This study \\
\hline Piraquara River - PR & $25^{\circ} 23^{\prime} 42^{\prime \prime}$ & $49^{\circ} 03^{\prime} 20^{\prime \prime}$ & 41.0 & 64.8 & 79.0 & This study \\
\hline $\begin{array}{l}\text { Represa dos } \\
\text { Alagados - PR }\end{array}$ & $25^{\circ} 00^{\prime} 00^{\prime \prime}$ & $50^{\circ} 00^{\prime} 00^{\prime \prime}$ & 41.0 & 70.4 & 93.0 & Gonçalves \& Rocha 2016 \\
\hline KM 119 River- PR & $23^{\circ} 28^{\prime} 47^{\prime \prime}$ & $52^{\circ} 21^{\prime} 19^{\prime \prime}$ & 18.5 & 33.1 & 58.4 & Carvalho et al., 2015 \\
\hline São Caetano River-MA & $07^{\circ} 52^{\prime} 49^{\prime \prime}$ & $46^{\circ} 03^{\prime} 96^{\prime \prime}$ & -- & 52.2 & -- & Oliveira et al., 2017 \\
\hline Parnaíba River - PI & $05^{\circ} 05^{\prime} 09^{\prime \prime}$ & $42^{\circ} 49^{\prime} 45^{\prime \prime}$ & 38.2 & 51.5 & 59.0 & Marçal \& Silva, 2017 \\
\hline Rio das Velhas - MG & $19^{\circ} 85^{\prime} 62^{\prime \prime}$ & $43^{\circ} 89^{\prime} 61^{\prime \prime}$ & -- & 56.0 & -- & Trindade et al., 2017 \\
\hline Igarapé Precuá - MA & $02^{\circ} 40^{\prime} 00^{\prime \prime}$ & $44^{\circ} 02^{\prime} 00^{\prime \prime}$ & 38.7 & 51.5 & 60.7 & Amorim et al., 2017 \\
\hline Aningas River - SE & $88^{\circ} 81^{\prime} 85^{\prime \prime}$ & $77^{\circ} 08^{\prime} 69^{\prime \prime}$ & 65.0 & 68.8 & 75.0 & Santos et al., 2016 \\
\hline Caiabi River - MT & $68^{\circ} 50^{\prime} 00^{\prime \prime}$ & $86^{\circ} 45^{\prime} 00^{\prime \prime}$ & -- & 76.0 & -- & Andrietti et al., 2016 \\
\hline Pará River - PA & $01^{\circ} 10^{\prime} 00^{\prime \prime}$ & $48^{\circ} 40^{\prime} 00^{\prime \prime}$ & -- & 59.6 & -- & Pereira \& Vieira, 2016 \\
\hline Arienga River - PA & $74^{\circ} 49^{\prime} 45^{\prime \prime}$ & $98^{\circ} 22^{\prime} 50^{\prime \prime}$ & 56.3 & 63.6 & 90.9 & Piratoba et al., 2017 \\
\hline Mourão River - PR & $24^{\circ} 42^{\prime} 57^{\prime \prime}$ & $52^{\circ} 07^{\prime} 03^{\prime \prime}$ & 60.0 & 41.1 & 70.0 & Passig et al., 2015 \\
\hline
\end{tabular}




\section{Control charts for individual measurements}

The WQI data from the Passaúna and Piraquara rivers show a normal distribution, at the 5\% level of significance, by the Anderson-Darling test. Figure 1 shows the individual Shewhart control graph, along with the reference ranges determined by ANA (2016) for the WQI values in the Passaúna (Figure 1a) and Piraquara (Figure 1b) rivers.

The WQI of the Passaúna River (Figure 1a) is out of statistical control, since it presents a point below the bottom line of control in 2006. Another characteristic that demonstrates the lack of statistical control is the existence of a sequence-type configuration. According to Ferreira et al. (2016) the process is out of statistical control when points outside the statistical control limit are detected, and/or when there is a sequence of points above or below the midline, confirming the observations already made. The Passaúna River, between 1987 and 2004, presents WQI values, alternating between good $(71<\mathrm{WQI} \leq 90)$ and medium $(51<\mathrm{WQI} \leq 70)$. Being the majority class of WQI the average quality. However, from the year 2004 it is possible to visualize that several points are located between $26<$ WQI $\leq 50$, characterizing a water of bad quality. In addition, in 2006 the water quality was measured as very poor.
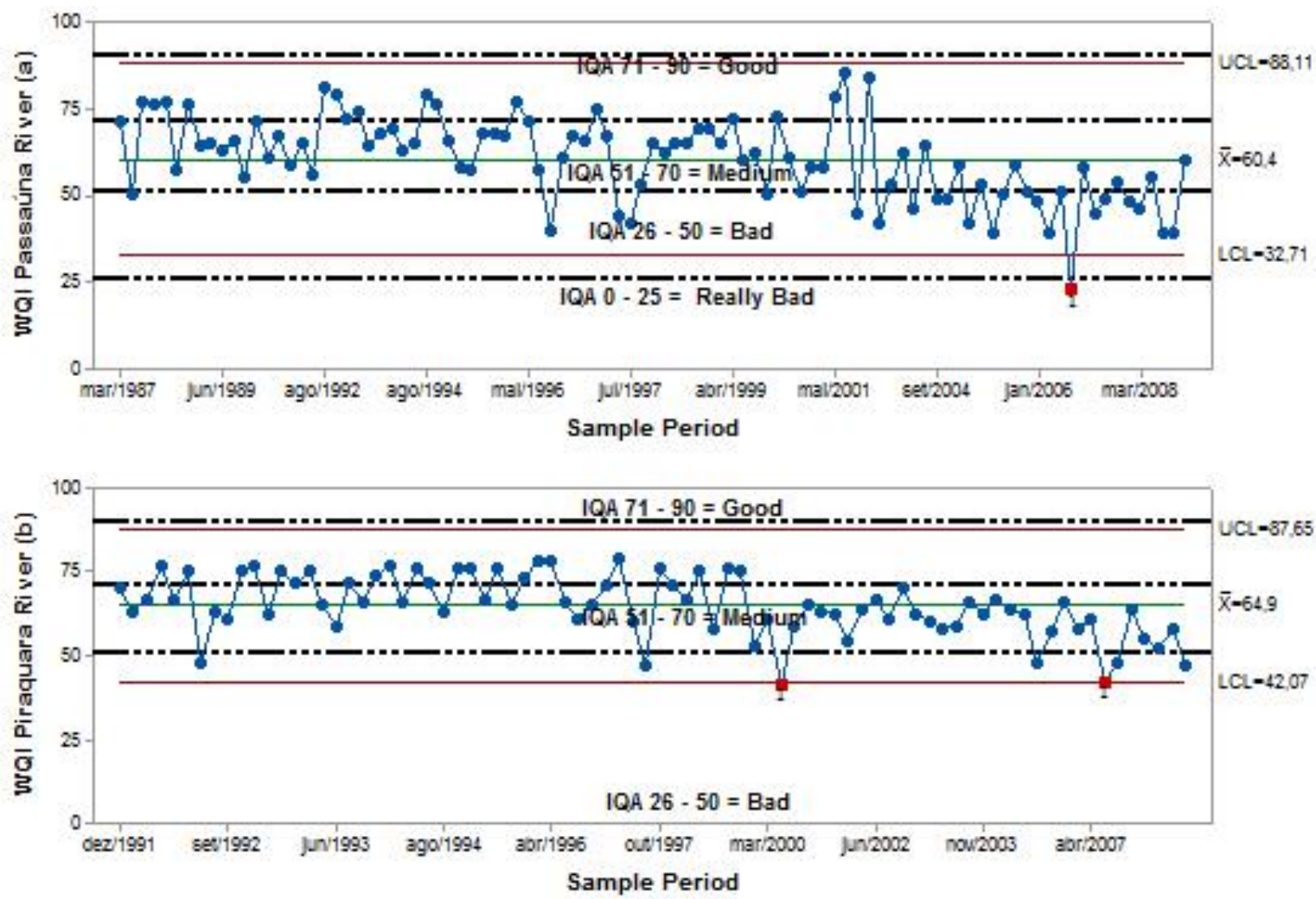

FIGURE 1. Shewhart charts for the water quality index for the Passaúna (a) and Piraquara (b) rivers, with reference lines from the National Water Agency.

The WQI of the Piraquara River (Figure 1b) is out of statistical control, as it presents points below the bottom line of control. Another characteristic that demonstrates the lack of control is the configuration of the sequence type. The Piraquara River between 1991 and 2000 presented WQI values, alternating between good (71 $<\mathrm{WQI} \leq 90)$ and medium $(51<\mathrm{WQI} \leq 70)$, with the exception of one point that presented poor WQI $(26<\mathrm{WQI}$ $\leq 50)$ in the year of 1992 . However, there are still some points in the portion of $26<\mathrm{WQI} \leq 50$, characterizing a poor quality, from the year 2000, where two of these points end up leaving the lower control limit, leaving the process more unstable.

Both rivers had few points outside the control limits, possibly due to external factors. There are several factors that contribute to environmental degradation, but in this sense, the external factors that were identified by Figure 1 could be attributed to the precipitation volumes, which reached an average of $1376.1 \mathrm{~mm}$ for the Campina das Pedras station - Passaúna river, and 1409,5 mm for Piraquara Station - Piraquara River; or even punctual discharges of sewage. However, the impact of urbanization can be identified from the 2000 s years, where both graphs show a decline in quality.

The individual Shewhart control chart is appropriate to monitor the pollution levels of a river (Lee et al., 2013, Reis et al., 2011, Vilas Boas et al., 2016). However, Lee et al. (2013) recommend complementary studies using the EWMA and CUSUM graphs, since they are more efficient when the mean displacement of the process is small.

Figure 2 shows the exponentially weighted moving average (EWMA) graphs of the WQI variable in the Passaúna (Figure 2a) and Piraquara (Figure 2b) rivers. The Rio Passaúna EWMA control graph (Figure 1a) demonstrates that the WQI variable is out of statistical control, because it presents sequential sets. In addition, after 2004, all points are below the bottom line of control, evidencing the instability of the process. A decreasing trend in the dataset was identified starting in 2001, characterizing a reduction in the water quality of the Passaúna River. 

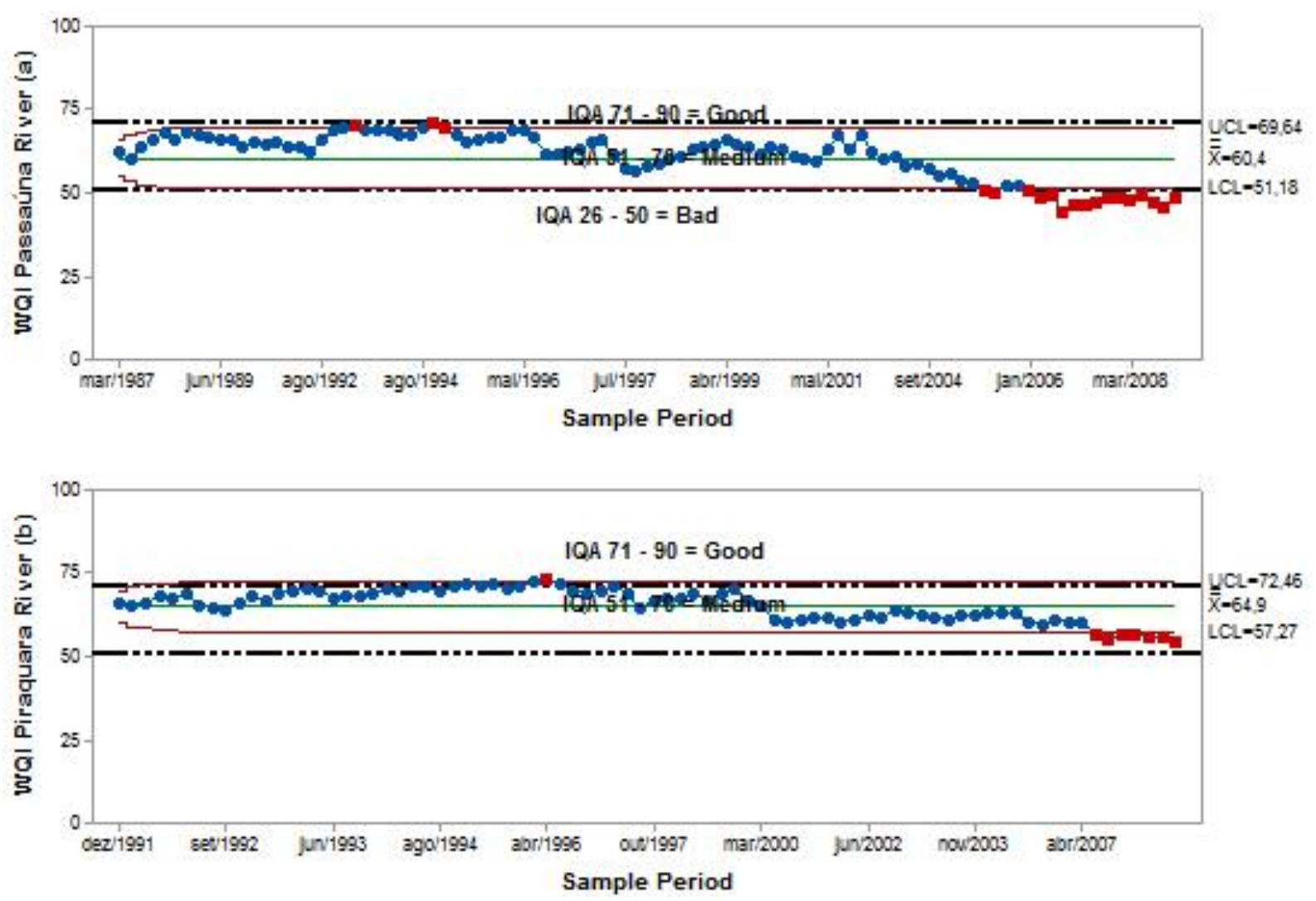

FIGURE 2. An exponentially weighted moving average graph for the water quality index of the Passaúna (a) and Piraquara (b) rivers, with reference lines of the National Water Agency.

The EWMA control graph of the Piraquara River (Figure 2b) shows that the WQI variable is out of statistical control because it presents sequential sets. After 2007, all points are below the bottom line of control, once again showing the instability in the WQI quality. The decreasing trend in this graph is even more evident than the previous one, demonstrating the decline since 1999, again showing a decrease in water quality.

Figure 3 shows the cumulative sum control graphs (CUSUM) of the WQI variable in the Passaúna (Figure 3a) and Piraquara (Figure 3b) rivers. The CUSUM control chart of the WQI of the Passaúna River (Figure 3a) demonstrates the instability of the WQI values between 1992 and 1999, where the points extrapolated the upper control limit, despite the instability detected by the graph, the extrapolation of the limit is beneficial, so that, for this to happen it is necessary that the WQI values be high, being within the highest quality classifications of the test. Another evidence of instability is the sequence of points that extrapolates the lower control limit, starting in 2005 , showing a decreasing trend.

The CUSUM control chart for the WQI of the Piraquara River (Figure 3b) demonstrates the instability of the values between 1994 and 1998, where the points extrapolate the upper control line of the graph. After that date the WQI decrease is evident. Another characteristic that shows the instability is the formation of sequence of points that extrapolate the lower limit of control, from the year of 2007, demonstrating a decreasing trend. Follador et al. (2012a) used the CUSUM charts to assess the quality of the Mandurim River and concluded that this methodology is dynamic to monitor the water quality process of the river.

The application of the control charts of individual Shewhart, EWMA and CUSUM, shows the decrease in WQI quality, from the 2000s years, on the Passaúna and Piraquara rivers. This result comes from reducing the quality of all parameters analyzed. The reduction of the WQI of the Passaúna and Piraquara river is influenced by the urbanization, since the points sampled are downstream of the urban centers of the respective cities. This behavior, to reduce the quality of water downstream from urban areas, was described by Moyel \& Hussain (2016) and Li et al. (2016). This hypothesis is confirmed because, since the 2000s years, the thermotolerant coliform parameter has sometimes exceeded the maximum limit allowed by CONAMA Resolution No. 357/2005, which may be justified by the growing population demand in the region. 

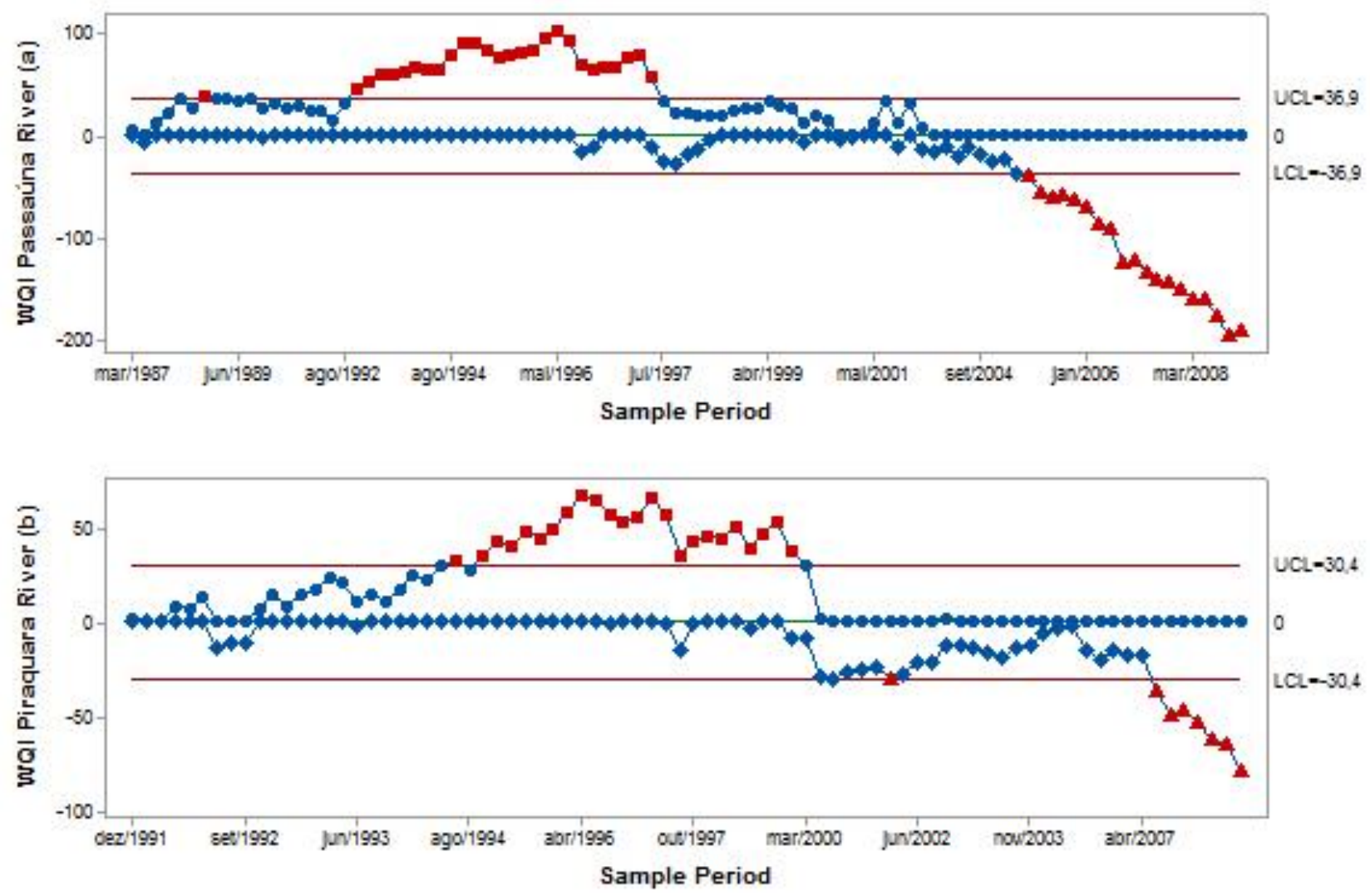

FIGURE 3. Cumulative sum control graphs (CUSUM) for WQI of Passaúna (a) and Piraquara (b) rivers.

According to data from IBGE (2017), the city of Araucária had 61,889 inhabitants in 1991 increasing to 119,123 people in 2010. Piraquara had 106,882 people in 1991 and decreased to 93,207 in 2010. Evidence indicates that the increase in the number of individuals could be contributing to the quality of the Passaúna river, lower than the Piraquara river. The population increase, together with the high rates of thermotolerant coliforms, could show the contamination of the Passaúna and Piraquara rivers by domestic sewage. Li et al. (2016) report that the water quality of the Qu River in Sichuan, China, showed a decreasing trend due to rapid population growth and industrial development. These factors contribute to the increase of residual discharges in the aquatic systems, thus reducing the quality of the water.

The EWMA control chart showed a better ability to evaluate the WQI data of the Passaúna and Piraquara rivers compared to the individual Shewhart and CUSUM charts. This superiority was identified because the EWMA graph had greater sensitivity to express what might have happened to the dataset (Follador et al., 2012b; Orsatto et al., 2015). These techniques of statistical control are effectively applied in the industrial sphere, however, they have been shown to be effective in identifying changes in water quality and can therefore be applied for this purpose.

\section{Analysis of the process capability index}

For the calculation of the process capacity index it is necessary to establish the lower limit of control (LCL) and upper limit of control (UCL). In this sense, the limits of the process capacity index for the WQI of the Passaúna and Piraquara rivers were established as: $\mathrm{LCL}=51$, since it is the minimum level established by the National Water Agency; and UCL $=100$, since it is the maximum level established by the National Water Agency. Figure 4a shows the histogram of the WQI of the Passaúna River in which it is possible to observe that the variation of the normal distribution extrapolates the range of the specification limits, classifying the process as unsatisfactory (Montgomery, 2004). The WQI of the Passaúna River presented $\mathrm{C}_{\mathrm{p}}=0.88$ and $\mathrm{C}_{\mathrm{pk}}=0.34$. According to Montgomery (2004) values of $C_{p}$ and $C_{p k}$ $<1.0$ are considered inadequate, confirming what was identified by the control charts and the histogram. 
WQI Passaúna River (a)

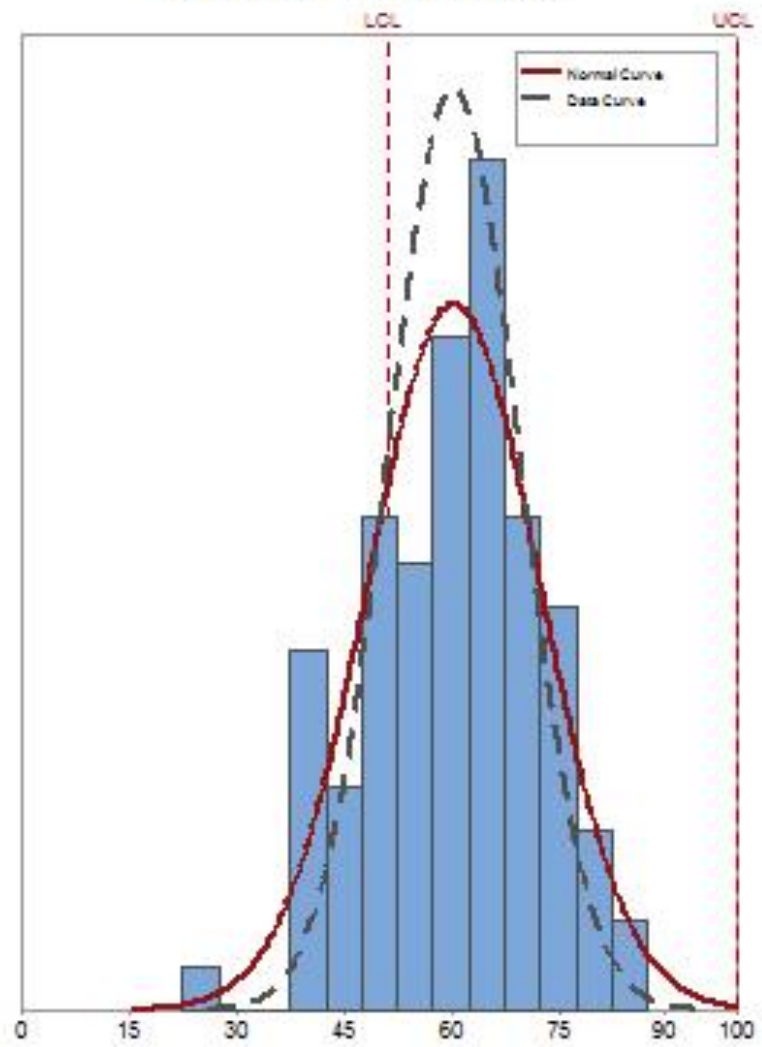

WQI Piraquara River (b)

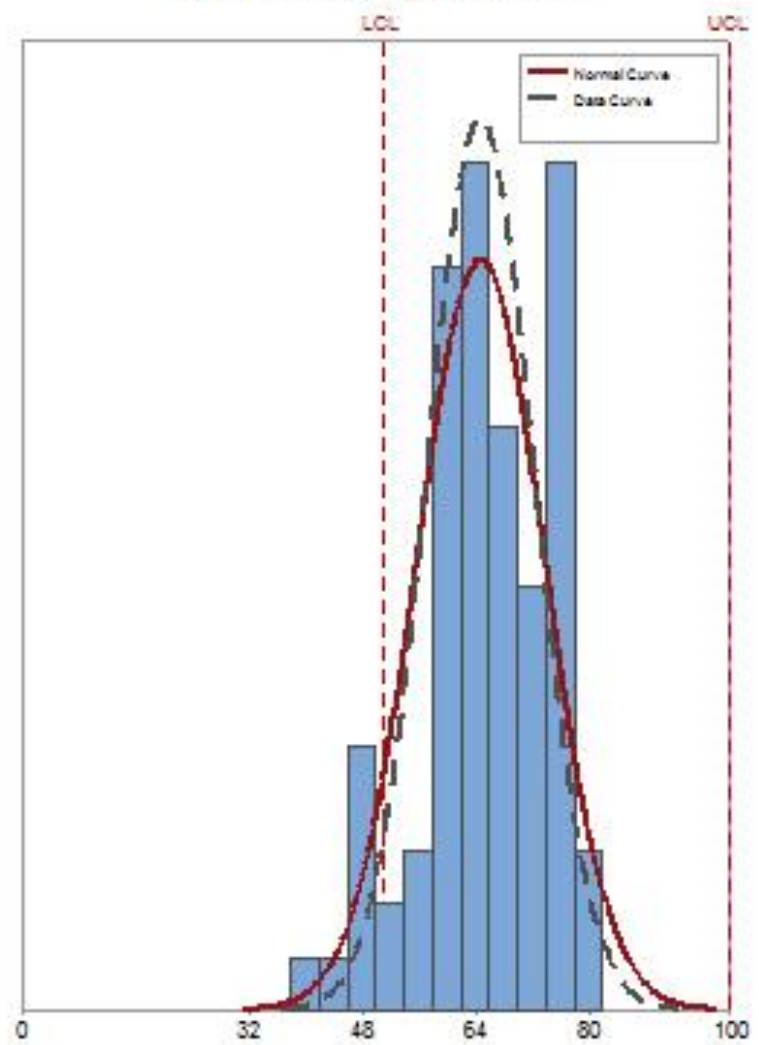

FIGURE 4. Process capacity for WQI of the Passaúna and Piraquara rivers.

Figure $4 \mathrm{~b}$ shows the histogram of the WQI of the Piraquara river, which shows a variation in the normal distribution, in relation to the range of specification limits, leaving the process possibly capable. The WQI capacity index of the Piraquara river is considered acceptable $\left(\mathrm{C}_{\mathrm{p}}=\right.$ 1.07) and meets the quality specifications. However, the capacity index $\mathrm{C}_{\mathrm{pk}}(0.61)$ is considered incapable, according to the classification proposed by Montgomery (2004). Therefore, the quality of the process capacity index of the Piraquara river was higher than that found for the Passaúna river as established by the EWMA control charts. Statistical process control and process capability index are efficient tools for several areas of knowledge, being more applied in industry to verify the quality of the process. However, this study demonstrates that these control tools are statistical methods applicable to monitoring water quality. Other studies in the environmental area also demonstrate the efficiency of quality tools, for example, Shaban (2014) considers that the process capability index is a versatile tool when studying a way to develop a management model to help with water reuse and the elimination of possible health risks to the population.

\section{CONCLUSIONS}

The statistical process control tools were efficient for monitoring the water quality of the rivers. The Exponentially Weighted Moving Average control chart was the most appropriate tool for the data set of the Passaúna and Piraquara rivers.
The Passaúna and Piraquara Rivers present medium quality water according to the Water Quality Index. However, it can be observed that the water quality of the rivers showed a decrease from the year 2000. This decrease in quality was possibly caused by the population increase and the urbanization in the drainage basin of the rivers.

\section{REFERENCES}

ANA - Agência Nacional das Águas (2016) Portal de qualidade das águas. Available in:

http://portalpnqa.ana.gov.br/indicadores-indiceaguas.aspx. Accessed: Apr 15, 2016.

Amorim DG, Cavalcante PRS, Soares LS, Amorim PEC (2017) Enquadramento e avaliação do índice de qualidade da água dos igarapés Rabo de Porco e Precuá, localizados na área da Refinaria Premium I, município de Bacabeira (MA). Engenharia Sanitária e Ambiental 22(2):251-259. DOI: http://dx.doi.org/10.1590/s1413-41522016131212

Andrietti G, Freire R, Amaral AG, Almeida FT, Bongiovani MC, Schneider RM (2016) Índices de qualidade da água e de estado trófico do rio Caiabi, MT. Revista Ambiente \& Água 11(1):162-175. DOI: http://dx.doi.org/10.4136/ambi-agua.1769

BRASIL Ministério do Meio Ambiente. Conselho Nacional de Meio Ambiente. Resolução nº 430, de 13 de maio de 2011. Dispõe sobre as condições e padrões de lançamento de efluentes, complementa e altera a resolução $\mathrm{n}^{\circ} .357$, de 17 de março de 2005.9 p. Diário Oficial da União, Brasília - DF, n 92, p. 89, 16 maio de 2011. Available in: http://www.mma.gov.br/port/conama/legiabre.cfm?codlegi=6 46. Accessed: Oct 25, 2016. 
Carvalho AP, Balduino AR, Maciel GF, Picanço AP (2016) Avaliação da poluição em rios utilizando índices de qualidade da água: um estudo de caso no ribeirão São João em Porto Nacional - TO. Geociências 35(3):472-484.

Carvalho KQ, Lima SB, Passig FH, Gusmão LK, Souza DC, Kreutz C, Belini AD, Arates EJ (2015) Influence of urban área on the water quality of the Campo River basin, Paraná State, Brasil. Brazilian Journal Biology 75(4):96106. DOI: http://dx.doi.org/10.1590/15196984.00413suppl

Fernandes NC, Scalize OS (2015) Comparação entre dois métodos para determinação da qualidade da água tratada. Ciência \& Engenharia 24(2):85-93. DOI: http://dx.doi.org/10.14393/19834071.2015.30122

Ferreira EB, Nomelini QSS, Oliveira MS (2016) O controle estatístico do processo na manufatura de autopeças. Revista da Universidade Vale do rio Verde 14(1):72-87. DOI:

http://dx.doi.org/10.5892/ruvrd.v14i1.2681

Frigo JP, Vilas Boas MA, Frigo JP, Frigo EP (2016) Comparação entre gráficos de controle de Shewhart, CUSUM e MMEP no processo de irrigação por aspersão convencional. Irriga 1(1):56-70. DOI: http://dx.doi.org/10.15809/irriga.2016v1n01p56-70

Follador FAC, Vilas Boas MA, Schoenhals M, Hermes E, Rech C (2012a) Tabular CUSUM control charts of chemical variables applied to the control of surface water quality. Engenharia Agrícola 32(5):951-960. DOI: http://dx.doi.org/10.1590/S0100-69162012000500014

Follador FAC, Vilas Boas MA, Malmann L, Schoenhals M, Villwock R (2012b) Controle de qualidade da água medido através de cartas de controle de Shewhart, CUSUM e MMEP. Engenharia Ambiental 9(3):183-197.

Giron E, Opazo MAU, Rocha Júnior WF, Gimenes RMT (2013) Aplicação do controle estatístico de processo em uma empresa do setor avícola. Revista de administração e inovação 10(4):38-62. DOI:

http://dx.doi.org/10.5773/rai.v10i4.891

Gonçalves DRP, Rocha CH (2016) Indicadores de qualidade da água e padrões de uso da terra em bacias hidrográficas no Estado do Paraná. Pesquisa Agropecuária Brasileira 51(9):1172-1183. DOI: 10.1590/s0100204x2016000900017

IBGE - Instituto Brasileiro de Geografia e Estatística (2017) Evolução populacional. Available in: http://ibge.gov.br/cidadesat/painel/populacao.php?codmun $=410180 \&$ search=parana $\% 7$ Caraucaria $\% 7$ Cinphographics: -demographic-evolution-and-age-pyramid\&lang=. Accessed: Jul 28, 2017.

Lee P, Huang Y, Kou T, Wang C (2013) The effect of the individual chart with variable control limits on the river pollution monitoring. Quality and Quantity 47(1):18031812. DOI: http://dx.doi.org/10.1002/env.2382
Li R, Zou Z, An Y (2016) Water quality assessment in Qu river based on fuzzy water pollution index method. Journal of Environmental Sciences 3(30):1-6. DOI: http://dx.doi.org/10.1016/j.jes.2016.03.030

Marçal DA, Silva CE (2017) Avaliação do impacto do efluente da estação de tratamento de esgoto ETE-Pirajá sobre o Rio Parnaíba, Teresina (PI). Engenharia Sanitária e Ambiental 22(4):761-772. DOI: http://dx.doi.org/10.1590/s1413-41522017148242

MINITAB (2017) User' guide. Release 17 for Windows. USA.

Montgomery CD (2004) Introdução ao controle estatístico do processo. Rio de Janeiro, LTC, 4 ed.

Moyel MS, Hussain NA (2016) Water quality assessment of the Shatt al-Arab river, Southern Iraq. Journal of Coastal Life Medicine 3(6):459-465. DOI: http://dx.doi.org/10.12980/JCLM.3.2015J5-26

Oliveira RMM, Santos EV, Lima KC (2017) Avaliação da qualidade da água do riacho São Caetano, de Balsas (MA), com base em parâmetros físicos, químicos e microbiológicos. Engenharia Sanitária e Ambiental 22(3):1523-1530. DOI: http://dx.doi.org/10.1590/s141341522017154657

Oliveira Pinto CU, Carvalho AP, Cavalcanti e Silva DGK (2015) Uso do WQI para a caracterização da água usada como insumo produtivo pela Comunidade Quilombola Malhadinha. Biota Amazônia 5(4):1-3. DOI: http://dx.doi.org/10.18561/21795746/biotaamazonia.v5n4p1-3

Orsatto F, Vilas Boas M, Eyng E (2015) Gráfico de controle da média móvel exponencialmente ponderada: aplicação na operação e monitoramento de uma estação de tratamento do esgoto. Engenharia Sanitária e Ambiental 20(4):543-550. DOI: http://dx.doi.org/10.1590/S141341522015020040093742

Passig FH, Lima SB, Carvalho KQ, Halmeman MCR, Souza PC, Gusmão LK (2015) Monitoring of urban and rural basins: water quality of Mourão basin. Brazilian Journal Biology 75(4):158-164. DOI: http://dx.doi.org/10.1590/1519-6984.01213suppl

Pereira FS, Vieira ICG (2016) Expansão urbana da Região Metropolitana de Belém sob a ótica de um sistema de índices de sustentabilidade. Revista Ambiente \& Água 11(3):731-744. DOI: http://dx.doi.org/10.4136/ambi-agua.1878

Piratoba ARA, Ribeiro HMC, Morales GP, Gonçalves WG (2017) Caracterização de parâmetros de qualidade da água na área portuária de Barcarena, PA, Brasil. Revista Ambiental \& Água 12(3):435-456. DOI: http://dx.doi.org/10.4136/ambi-agua.1910 
Reis CF, Vilas Boas MA, Hermes E, Reisdorfer M (2011)

Avaliação da qualidade da água para irrigação em Salto do Lontra - PR. Engenharia Ambiental: Pesquisa e Tecnologia 8(1):69-78.

Santos RCL, Lima AS, Cavalcanti EB, Melo CM, Marques MN (2018) Aplicação de índices para avaliação da qualidade da água da Bacia Costeira do Sapucaia em Sergipe. Engenharia Sanitária e Ambiental 23(1):33-46. DOI: http://dx.doi.org/10.1590/S1413-41522017159832

Shaban M (2014) Drainage water reuse: state of control and process capability evaluation. Water Air Soil Pollution 225:2168. DOI: http://dx.doi.org/10.1007/s11270-014-2168-6
Trindade ALC, Almeida KCB, Barbosa PE, Oliveira SMAC (2017) Tendências temporais e espaciais da qualidade das águas superficiais da sub-bacia do Rio das Velhas, estado de Minas Gerais. Engenharia Sanitária e Ambiental 22(1):13-24. DOI:

http://dx.doi.org/10.1590/s1413-41522016131457

Vilas Boas MA, Poleto C, Juchen RT, Juchen CR (2016) Analysis of urban rivers' water quality using multivariate approach. International Journal Environmental Engineering 8(1):30-43. DOI:

http://dx.doi.org/10.1504/IJEE.2016.078238 